\title{
Is Temporary Protection Eternal? The Future of Temporary Protection Status of Syrians in Turkey
}

\author{
Esra Y1lmaz Eren ${ }^{ \pm}$
}

\begin{abstract}
Turkey has provided temporary protection status for the Syrian people, who were accepted by "open door policy" and sheltered as "guests" until the situation in Syria ameliorates. Temporary protection, a convenient tool to respond to the mass influx and provide protection while a permanent solution is sought, is indeed designed as an interim solution. After seven years of conflict, it can be assumed that peace and security cannot be established in Syria in a short period of time, as a consequence, Syrians shall continue staying in Turkey longer than anticipated. Therefore, congruent with the meaning of temporary protection status, it is time for Turkey to collaborate with international society in terms of burden-sharing on the one hand, to terminate temporary protection regime, and to determine its own strategies to provide permanent solution on the other.
\end{abstract}

Keywords: Temporary Protection; Syrians in Turkey; Refugee Law; Termination of Temporary Protection; Permanent Solution.

\section{Introduction}

Turkey, as a host country, has provided temporary protection status with the Law on Foreigners and International Protection (hereinafter LFIP) for the Syrians. "Temporary protection" has been a convenient tool for the protection of persons of masses who were forced to leave their countries due to civil wars, wide-spread human rights violations and natural disasters. It functions to provide urgent help to people in immense without any individual asylum status determination as well as long bureaucratic procedures. On the other hand, temporary protection is an interim measure for international protection aiming to protect people for a short period of time. Unless the condition in the country of origin is sufficient for voluntary return, in a reasonable time period, the protection should be transformed into a long term international protection.

\section{Temporary Protection in International Legislation}

\section{Temporary Protection Concept}

Temporary protection can be defined as a concept that has been created to protect displaced persons who has to migrate as a result of an emergency influx based on unpredictable and urgent situation like civil war, widespread human rights violations or natural disasters (Fitzpatrick, 2000: 279-282). In other words it can be defined as a type of protection afforded to foreigners who are

${ }^{ \pm}$Dr Esra Yılmaz Eren, Türkisch-Deutsche Universität, Lehrstuhl Für Allgemeines Öffentliches Recht, Şahinkaya Cad. No: 86 34820 Beykoz/ Istanbul, Turkey. E-mail: eren@tau.edu.tr.

Acknowledgement: This study was supported by Turkish - German University Scientific Research Projects Commission under the grant no: 2019BH0011. An earlier version of this paper was presented at the Migration Conference 2018, Universidade de Lisboa, Portugal, 26-28 June. 


\section{The Future of Temporary Protection Status of Syrians in Turkey}

forced to leave the country, unable to return and take sanctuary to seek out an immediate and temporary protection. Particularly, it applies to situations which carry a potential risk that the standard asylum system is insufficient to cope with demand stemming from a mass influx. The major aim of temporary protection is to grant these persons settlements in safe places immiadiately and guarantee their fundamental human rights including non-refoulement.

Temporary protection has been applied in mass influx events as practiced by England and France for people fleeing from Spanish civil war in 1930s (Perluss \& Hartman, 1985: 559), by Indonesia, Hong Kong, the Philippines, Thailand and Malaysia, in the framework of the Comprehensive Action Plan, as they provided protection for more than one million Vietnamese people who had to escape due to human right violations and economic difficulties in Vietnam (Fitzpatrick, 2000: 283). Southeast countries' protection covered for those until their resettlement in the USA or France can be regarded as temporary protection as well.

Although there existed such early applications, the concept has come to the European agenda with the Former Yugoslavia crisis in the 1990s (Fitzpatrick, 2000: 286). Multiple solutions have been proposed to ensure the protection of thousands of people who were displaced within a very short period of time due to the violent war, armed conflict and ethnic cleansing that have occurred in the middle of Europe (UNHCR, 1992). In the first stage, it was considered more convenient to establish safe zones that can protect people from hot conflict areas without having to leave their home countries. However, the massacres that took place in Srebrenica and Zepai have manifested that protecting Former Yugoslavia is far from possible. In the next stage, UNHCR has declared that the border countries should open their borders for those in need of protection, at least for a short term. This can actually be regarded as the first legal instrument for temporary protection (UNHCR, 1992).

As a response to this demand, European countries welcomed the asylum seekers and provided protection on a temporary basis in their own circumstances based on their own regulations until the end of the war. There might be two reasons why the host states tend not to apply ordinary asylum system but adopt a new approach. In the first place, persons in concern could not be regarded as refugees according to the 1951 Geneva Convention since they have left their countries of origin due to a civil war or widespread human rights violations, which are not among the reasons stated numerous clausus in 1951 Convention. The second reason relates to the case when the country of reception (or any other country) lacks adequate resources to assess the statues of people in need of protection because of their insurmountably huge population even though they may possess the requisite conditions to be regarded as refugees. Therefore, the host country may assess the situation as group-based and provide temporary protection as a whole. In both cases, people are transported from places where their lives are in danger. In this way, an urgent solution is found for them since temporary protection is a convenient tool to protect people without any delay and bureaucratic procedures.

Furthermore, in some cases, temporary protection offers a breath-taking break to states experiencing a massive influx, to decide how to deal with this influx while providing immediate protection. After a certain period of time, which may range from a few months to a few years, the states are expected to find a permanent solution like recognition of asylum or return to their country of origin or resettlement (Yakoob, 1999: 618) and by providing group-based determination, this statue helps to save time and money. Thus it is regarded as a pragmatic form of protection (UNHCR, 1994: para. 45). 


\section{Temporary Protection Application in European Union}

During the 1990s, conflicts in the former Yugoslavia brought about the need for special procedures to deal with mass influxes of displaced persons in the EU. Since there was no determined binding legal instrument or international legislation on conditions and limits of temporary protection then; European countries, who welcomed the asylum seekers from Former Yugoslavia due to civil war, provided different types of protection in their own circumstances based on their own interpretations. Rather than making a new status determination, Germany provided duldung, UK exceptional leave to remain and other European countries $B$ or $F$ status and ensured protection until the end of the war (Selm-Thorburn, 1998: 198-200; Akram \& Rempel, 2004). Therefore, the rights and obligations of asylum seekers are fulfilled according to the internal and external factors, and thus differentiated within Member states, (Fitzpatrick, 2000: 285, 286) and accordingly the need for an overall operation in third column to guarantee burden-sharing and a uniform application all over the EU countries have emerged. Afterwards in order to eliminate the differences and to respond to this crucial need "Council Directive on minimum standards for giving temporary protection in the event of a mass influx of displaced persons and on measures promoting a balance of efforts between member states in receiving such persons and bearing the consequences thereof" (hereinafter TP Directive) was adopted on 20 July 2001 and with this Directive, an exceptional mechanism and a binding temporary asylum system that aims to provide fair burden sharing has been established (Arenas, 2005: 437). This directive which can be regarded as an ultimate consequence of approximately ten-year study yet has never been used in the Union -even for the current Syrian crisis-.

"Mass influx" concept has formed the distinguishing feature of this new approach and was defined as "a large number of displaced persons from a third country or geographical area" (TP Directive, Art. 2/d). The Directive aims to establish minimum standards for giving temporary protection in the event of a mass influx of displaced persons from third countries who are unable to return to their country of origin and to promote a balance of effort between the Member States in receiving and bearing the consequences of receiving such persons. While giving a wide discretionary power for the host states, the "rights" of the temporary protected people have never been articulated, contrarily the Directive prefers to use the "services" that the State will provide or the "responsibilities" of the host state. Such wording is considered to underline the inclination that temporary protection status does not sustain any demandable rights for the asylees, rather it holds host states responsible for meeting the minimum basic needs of temporary protected (Kerber, 2002: 201). In the same way, article 3 of the Directive only envisages the Member States to respect human rights and fundamental freedoms (including non-refoulement) of asylum seekers even though paragraph 5 of the same article states that Directive shall not affect the prerogative of the Member States to adopt or retain more favourable conditions for persons covered by temporary protection. Thus, it can be assumed that the Directive determines the minimum standards for this regime and it is in the discretion of each Member State to provide more. Accordingly, it regulates some services or responsibilities that host states may provide, if they desire; including residence permits, visa, information and readmission, registration data protection, housing and social welfare and health benefits, education and family reunification, and compliance with provisions relating to unaccompanied minors as health services, education services, access to labour market services, services for people who have special needs.

To sum up, the basic philosophy of the temporary protection regime, which can be regarded as pragmatic and complementary tool to provide international protection in large-scale influx, is to ensure that people who have been forced to leave their country massively on the grounds of such 


\section{The Future of Temporary Protection Status of Syrians in Turkey}

reasons as armed conflict, widespread violence, human rights violations and natural disasters have access to a safe place and protection from being sent back to their country of origin; and to meet their urgent and basic needs (UNHCR Guidelines, 2014: 2). However, while accepting these persons, European countries acted based on the assumption that asylees do not have the intention to leave their home countries permanently, on the contrary, they need protection for a short period of time and when the situation in the country of origin is stabled, they will return back (Akram \& Rempel, 2004: 12). Thus, a new asylum approach aiming to protect all those who have escaped from areas of widespread conflict and human rights violations without any legal status determination and to send them back to their countries after the end of the war was implemented (UNHCR Roundtable, 2012: 1-3). Temporary protection ensures protection for a wider audience from a limited number of defined refugees under the 1951 Geneva Convention compared to international refugee protection, on the other hand, rights entitled to refugees are much more comprehensive. Besides, temporary protection contains only minimum protection elements as acceptance to the country, complying with fundamental rights and non-refoulment principle along with basic needs such as access to nutrition, housing and emergency health services (Akram \& Rempel, 2004: 12). Thus, people benefitting from temporary protection have a position between asylum seekers and 1951 Convention refugees.

TP Directive has pivotal importance for Turkey since the temporary protection regime that Syrians are subject to has been established broadly on the basis of TP Directive and European practice. While the legal infrastructure for Syrians in Turkey is based on LFIP, the detailed arrangements are located in the Temporary Protection Regulation, which has mainly been prepared based on the TP Directive.

\section{Temporary Protection in Turkey}

\section{In general}

Turkey has provided temporary protection status for the Syrian people who were accepted by "open door policy" and sheltered them as "guests" until the situation in Syria is stable. Temporary protection served as an interim response to the mass influx, providing safety while a durable solution is sought. After LFIP, temporary protection category which is used to protect masses has been added to the international protection categories of Turkish law (refugee, conditional refugee and subsidiary protection). Turkish legal text forming the temporary protection system mainly based on European practice. TP Regulation has envisaged that temporary protected people may be provided with health, education, access to the labor market, social assistance and very similar services that are regulated by EC Temporary Protection Directive.

\section{Termination of Temporary Protection Status}

The duration, application and end of temporary protection regime of great importance for the host states to fulfil its international obligations to protect refugees. It is important to terminate the temporary protection status -when the conditions are met- after a reasonable time. Otherwise, support of the states to provide temporary protection shall decrease. In this context, common criteria for the termination of temporary protection status should be determined; not only to indicate that the hospitality of states has a limit, but also to avoid human right violations that might occur due to repatriation of people as a result of the exhaustion caused by the whole protection procedure (Fitzpatrick, 1999: 345). 
According to TP Directive, the TP status shall come to an end when the maximum duration has been reached or when the Council decides that there is no longer $a$ need to provide protection. Even though the Council may decide to terminate the regime at any time, this decision can not be taken arbitrarily and accordingly the Council should take into consideration whether the conditions in the country of origin is satisfactory for safe and durable return and also with due respect for fundamental rights and freedoms and states' obligations concerning non-refoulement (TP Directive, Art.6/2). In other words, it is necessary to determine that the situations like war or internal conflict, which resulted in the mass migration, no longer exist, as well as peace is maintained, human rights are respected and the rule of law is guaranteed in the country of origin.

On the other hand, regarding Turkey, Temporary Protection Regulation (hereinafter TP Regulation) does not foresee any limitation period. Article 10 of the TP Regulation holds that the Council of Ministers will determine the termination of temporary protection and along with this decision it may also decide to fully suspend the TP regime and send the temporary protected people back or to grant a status collectively or assess individual applications or lastly grant permission to all within condition stated by law (TP Regulation, Art. 11/2). Due to the non-existence of a certain time limitation, the need for criteria to determine the termination of the regime emerges. The legal basis of the temporary protection regime was initially established by the declaration of UNHCR, asking the border states to provide at least short-time protection for asylum seekers escaping from Former Yugoslavia civil war. According to this perspective, the postulate was people who need urgent protection do not have the intention to migrate. They only want to save their lives and they need a safe place and fundamental needs as shelter and food during the instability of their countries of origin. But when the conditions in their country are stable again, they will return. So, in the first place, temporary protection regime was a further step from safe zone areas in the country of conflict to protect the people in border countries for a short period of time. Therefore if the presumption comes true and the conflict ends in a considerable time, temporary protection is terminated and the country of reception accommodates people to return to their countries. In other words, the most desired solution for temporary protection is considered as "voluntary return". What if the presumption does not come outright and the armed conflict or human rights violation which resulted in a mass influx does not end in a reasonable time? How long should the country of reception continue providing temporary protection regime? As far as the temporary protection regime is an interim measure, it has to be applied for a reasonable time (Hathaway \& Neve, 1997: 181; Fitzpatrick, 2000: 302). However, it is not easy to determine what reasonable time is. Although it is not possible to determine a common time limit for all countries, The Temporary Protection Directive and the International Law Association have adopted a 3-year term (EC TP Directive, art. 4; ILA Report, 2002: 14), while many states like Sweden, France and Finland have integrated temporary protected people into ordinary asylum procedure systems after three years application of temporary protection. In terms of Former Yugoslavia crisis, Denmark, Norway and France have applied TP status for three years, while Germany has kept Former Yugoslavians under duldung over seven years (UNHCR, 1993: 160). On the other hand, USA has applied temporary protection status for seven years to people coming from Nicaragua and Cuba; at the end of 7 years, the termination of the regime and the return of the people to the country of origin is regulated (NACARA, 1997).

Taking into consideration the lack of common standards related to ending the temporary protection, 1951 Geneva Convention regulations on the termination of refugee status might be useful and guiding (UNHCR, 2013: para 24). In accordance with Article 1 (C), there are two ways in which states' responsibilities to refugees are abdicated in terms of the 1951 Geneva Convention. The first one may occur when the refugee himself returns to the country of his own accord and 


\section{The Future of Temporary Protection Status of Syrians in Turkey}

settles in his country of origin. At this point, it is significant to highlight that the physical return of the person by no means suffice but re-establishment is required along with voluntary return condition according to Article 1C (4) of the refugee. Otherwise, the return would cause in the states' infringement of non-refoulment principle (Hathaway, 2005: 202; Barutciski, 1998: 243). The second alternative could be made possible through radical changes in the conditions within the country of origin. Since the conditions that caused the displacement no longer exist, the statute will be terminated. Thus, the host country may be right to demand the person to return home.

Nevertheless, it is important to determine the legal and procedural conditions regarding the termination of refugee status due to change in the political conditions. For instance, if a person has fled because of internal conflicts and subsequent to his departure a new government has come to power through a general election in the country, in this case, would the change in the political condition be seen as a sufficient reason for the return of the person? Or, can any regional improvements in the country of origin be an adequate justification to claim the refugee's return home or to another region in his country? Put another way, how should it be decided that the refugee status has terminated due to radical conditional changes in the country of origin. As framed by UNHCR; there must be a change in the refugee's country of origin, which is fundamental, durable, and effective (ExCom Conclusion No 69). Thus, in the simplest form, both extinguishing the fear of persecution and restoration of protection is needed (UNHCR Cessation, 2003: 10-12). "The changes in the country of origin of refugees should be so profound and continuous that refugees should no longer need international protection and have no reason to refuse from benefiting from the protection of their own country" (UNHCR, 1991; UNHCR Cessation 2003, UNHCR, 2014: 5). The end of armed conflict and restoration of peace and democratic elections, declarations of amnesties, repeal of oppressive laws and dismantling of former security services are regarded as profound changes by UNHCR that indicates elimination of the persecution risk for the refugees (UNHCR, Note on Cessation, 1997: para 20).

To determine the common criteria for the termination of temporary protection, "Amended Proposal for a Joint Action Concerning Temporary Protection of Displaced Persons" composed by European Commission (COM 1998), "Progress Report on Informal Consultations on the Provision of International Protection to All Who Need It" prepared by UNHCR (UNHCR, 1997) can be regarded as primary sources since these texts not only propose a framework for the future mass influxes but also specify the minimum treatment requirements. In addition to these two important texts, the Dayton Agreement (Dayton Agreement, Annex 7, Art 1/2) should also be taken into account. Dayton agreement states that in order to ensure "safe return in humanitarian conditions"; the right of persons to return freely to their countries of origin, within security -physical and legal , respecting non-discrimination and freedom of travel, as well as family life, freedom of religion and freedom of thought and the right to property should be provided and also after the return, basic needs of returnees as assistance and shelter should be ensured to make the integration possible.

Besides, temporary protection can be terminated as long as the environment allows the beneficiaries of temporary protection to return to the country of origin in a safe and dignified manner. For a safe and honourable return; respect and compliance with the right of return by the country of origin; the existence of conditions for ensuring the physical and legal security of returnees, the existence of sufficient infrastructure to enable the return to be sustainable or the availability of basic life needs including food, shelter and basic sanitary and health facilities, the non-discrimination of the returnees and respect for other fundamental human rights should be provided. Furthermore, the return is preferably should be part of an international process or mechanism and if the return to the old habitat is not possible, then the return of the person to a 
region where he can live safely and honourably is sought. At this point, it is of great importance to prevent the repatriated person from becoming an internally displaced person who is struggling to live (UNHCR, 1997 Progress Report).

For cessation clause to be applicable in a civil war, UNHCR states that national protection must be effective. And in this context, national protection means more than mere physical security or safety, and includes apart from the prevalence of calm and security in the area concerned, the presence of a functioning governing authority, the existence of basic structures of administration including a functioning system of law and justice and the existence of adequate infrastructures to enable residents to exercise their right to a basic livelihood (UNHCR, Cessation, 1997: 25).

In other words, the conditions in the country of origin have reached to a certain level in which human rights are protected and general physical security is ensured and no new migration will occur (Fitzpatrick, 1999: 367); if there were an effective functioning authority, a fair legal system, it would then be possible to return (UNHCR, 2013: 15, 16).

For instance, the US Board of Immigration Appeals denied the applicant's allegation that the new Taliban regime was at risk of persecution, on the ground that the Communist regime in Afghanistan has ended and the threat of persecution was no longer present; on the other hand Australian Refugee Review Tribunal has upheld the conviction that a refugee from former Zaire, who had been tortured by the Mobutu regime, which claimed that the pressure towards the political party he used to serve continues from the new government, therefore, his fear of persecution had continued (Fitzpatrick, 1999: 367).

The termination of the temporary protection and adherence to the principle of non-refoulment in the return of the temporary protected persons to the countries of origin, the safety and dignity of return (UNHCR, 2001: para 20), to prevent persons from becoming internally displaced in their countries of origin and in order to prevent the violation of the rights of persons with special status before the return, the access to the usual asylum system must be recognised.

Bearing in mind the object of temporary protection, which is to ensure international protection to all those in need of it, the criteria for the withdrawal of such protection should take into account the individual's continuous need for it and may, therefore, apply differently among the beneficiaries. Even though the circumstances caused the mass influx has come to an end, the individual assessment procedure should be operated and the special conditions of temporary protected people should be taken into consideration (Hathaway \& Neve, 1997: 182). If temporarily protected persons have special reasons not to return back, then the host states should take these into consideration before repatriation.

The termination of temporary protection should -in principle- be undertaken only when it is considered that the beneficiaries would be able to return in safety and dignity, and when their return is sustainable. Returning should preferably take place voluntarily. The withdrawal of temporary protection should be without prejudice to the entitlement of an individual to invoke the principle of non-refoulment, or to seek recognition of refugee status. Definitive criteria for withdrawal of temporary protection are still being developed within the framework of the informal consultations and discussions organised by UNHCR as requested by the Executive Committee. Factors taken into consideration in the application of the "ceased circumstances" cessation clause under the 1951 Convention may serve as useful guidelines in the formulation of the criteria and may be referred to whenever appropriate. (UNHCR, Cessation, 1997: 27).

Furthermore, returnees need an effective system for monitoring the reintegration process through the establishment and functioning of local and international mechanisms that protect human rights. 


\section{The Future of Temporary Protection Status of Syrians in Turkey}

\section{Conclusion and Suggestions}

Turkey reveals a significant effort to Syrians since April 2011. Even though the temporary protection regime is regulated for temporary situations, the timing can not be always predicted easily. Turkey has shown the determination to set a legal basis for the current condition with LFIP and TP Regulation. Also providing international protection without any conditions to all people who are in need, is an appreciated application which also prevented wide-scale human rights violations. On the other hand, applying $a$ temporary protection regime, which is an interim measure, over seven years abolished the effectiveness of the protection.

It can be assumed that peace and security can not be established in Syria in a short period of time and along with that Turkey has to see the fact that most of the Syrian people will continue staying in Turkey and the support that might come from Western governments and international institutions is likely to be extremely low. On the other hand, application of temporary protection status more than seven years and making Syrians stay in purgatory without any permanent solutions (Kaya and Y1lmaz Eren, 2015), may lead to the ignorance of Turkey's full effort. Therefore, Turkey standing alone with the current situation has to find its own solutions and determine a policy to terminate temporary protection progressively and provide these people permanent international protection (resettlement or naturalisation).

At this point, it should be underlined that the refugee problem is an issue threating to the international community and it should not be regarded as the problem of only border countries. On the one hand, it is essential that States that accept refugees should continue accepting and helping the refugees despite all the problems, however, on the other hand, the responsibility and not only financial but also physical burden-sharing should be ensured by the international community. Otherwise, the border states may not be open to protection in the next time.

Also, international society tends to focus on the results generally; but it should not be forgotten that refugees are results. Instead, the international community should focus on reasons for refugee flows and find precautions to prevent new refugee influx. Since the main reason of mass influx is human rights violations or wars, UN human rights institutions has to find solutions as to monitor States, disapprove the violations by all the international community and appoint Special Rapporteurs to analyse special situations and making recommendations. In addition, some solutions can be achieved by supporting preventive diplomacy and conflict prevention mediation initiatives and through respecting principles of humanitarian law. At this point, a rare known international principle "the duty of the states not to create refugees" can be activated by the UN. Finally, the 1951 Geneva Convention is needed to be revised according to the new upcoming demands. 


\section{References}

Akram, S. M. \& Rempel, T. (2004), “Temporary Protection as an instrument or Implementing the Right of Return of Return for Palestinian Refugees”, Boston University International Law Journal, 22-1: 1- 162.

Amended Proposal for a Joint Action Concerning Temporary Protection of Displaced Persons, COM (1998), 372 final.

Arenas, N. (2005). "The Concept of "Mass Influx of Displaced Persons' in the European Directive Establishing the Temporary Protection System", European Journal of Migration and Law, 7: 435-450.

Barutciski, M. (1998). "Involuntary Repatriation when Refugee Protection is No Longer Necessary: Moving Forward After the 48th Session of the Executive Committee ”, International Journal of Refugee Law, 10 (1/2): 236- 255.

Eggli, A. V. (2002).Mass Refugee Influx and the Limits of Public International Law, Martinus Nijhoff Publishers.

Ekşi, N. (2014). "Geçici Koruma Yönetmeliği Uyarınca Geçici Korumanın Şartları, Geçici Koruma Usulü, Sağlanan Haklar ve Geçici Korumanın Sona Ermesi”, İstanbul Barosu Dergisi, 88 (6): 65-89.

European Council Directive 2001/55/EC of 20 July 2001 on Minimum Standards for Giving Temporary Protection in the Event of a Mass Influx of Displaced Persons and on Measures Promoting a Balance of Efforts between Member States in Receiving Such Persons and Bearing the Consequences thereof, OJ L212, 07.08.2001.

Fitzpatrick, J. (1999). "The End of Protection: Legal Standards for Cessation of Refugee Status and Withdrawal of Temporary Protection”, Georgetown Immigration Law Journal, 13: 343-381.

Fitzpatrick, J. (2000). “Temporary Protection of Refugees: Elements of a Formalized Regime”, American Journal of International Law (AJIL), 94: 279-306.

General Framework Agreement for Peace in Bosnia and Herzegovina, Annex 7.

Gibney, M. J. (2000). "Between Control and Humanitarianism: Temporary Protection in Contemporary Europe", Georgetown Immigration Law Journal, 14: 689-707.

Goodwin-Gill, G.\& McAdam, J. (2007).The Refugee in International Law, Oxford University Press.

Hathaway, J. C. (2005). "The Right of States to Repatriate Former Refugees", Ohio State Journal on Dispute Resolution, 20 (1): 201-242.

Hathaway, J. C.\&Neve, R. A. (1997). "Making International Refugee Law Relevant Again: A Proposal for Collectivized and Solution-Oriented Protection", Harv. Hum. Rts. J., 10: 115-211.

International Law Association (ILA) (2002).Report of the Committee on Refugee Procedures of the ILA, Final Report and Draft Guidelines on Temporary Protection. (Delhi Conference, 2002).

Joly, D. (2002). "Temporary Protection and the Bosnian Crisis: a Cornerstone of the New European Regime", In. D. Joly (ed) Global Changes in Asylum Regimes, Basingstoke: Palgrave/ Macmillan.

Kaya, İ.,\&Yılmaz Eren, E. (2015). Türkiye'deki Suriyelilerin Hukuki Durumu- Arada Kalanların Hakları ve Yükümlülükleri, İstanbul: Seta.

Kerber, K. (1999).“Temporary Protection in the European Union: A Chronology”, Georgetown Immigration Law Journal, 14 (1): 35-50.

Kerber, K. (2002).“The Temporary Protection Directive”, Eur. J. Migration \& L., 4: 193-214.

Koser, K., Walsh M. and Black R. (1998). "Temporary Protection and the Assisted Return of Refugees from the European Union”, International Journal of Refugee Law, 10: 444- 461.

Perluss D.\& Hartman J. F. (1985). “Temporary Refuge: Emergence of a Customary Norm”, Virginia Journal of International Law, 26: 551- 626.

Selm- Thorburn, J. (1998). Refugee Protection in Europe: Lessons of the Yugoslav Crisis, Martinus Nijhoff.

Sopf, D. (2001). "Temporary Protection in Europe After 1990: The "Right to Remain" of Genuine Convention Refugees", Journal of Law \& Policy, 6: 109-156.

Temporary Protection Regulation, http://www.goc.gov.tr/files/files/temptemp.pdf

The Nicaraguan Adjustment and Central American Relief Act (NACARA), (1997). Pub. L. No. 105-107, §201, 111 Stat. 2160.

UNHCR (1992), A Comprehensive Response to the Humanitarian Crisis in the Former Yugoslavia, 24 July 1992, HCR/IMFY/1992/2.

UNHCR (1993). The State of The World's Refugees- The Challenge of Protection, Penguin Books.

UNHCR (1994). Note on International Protection, Executive Committe, A/AC.96/830.

UNHCR (1997). Note on the Cessation Clauses, Executive Committe of the High Commissioner's Programme, 8. Meet. U.N. Doc. EC/47/SC/CRP.30. 


\section{The Future of Temporary Protection Status of Syrians in Turkey}

UNHCR (1997).Progress Report on Informal Consultations on the Provision of International Protection to All Who Need It, Executive Committe of the High Commissioner's Programme, 8th Meet, U.N. Doc. EC/47/SC/CRP.27.

UNHCR (2003). Guidelines on International Protection No. 3: Cessation of Refugee Status under Articles 1(c)(5) and (6) of the 1951 Convention relating to the Status of Refugees, U.N. GAOR, 58th Sess., 7, U.N. Doc. $\mathrm{HCR} / \mathrm{GIP} / 03 / 03$.

UNHCR (2012), Roundtable on Temporary Protection, 19-20 July 2012, International Institute of Humanitarian Law, San Remo, Italy: Summary Conclusions on Temporary Protection', 20 July 2012.

UNHCR (2014). Guidelines on Temporary Protection or Stay Arrangements, February 2014.

Yakoob, N. (1999). "Report on the Workshop on Temporary Protection: Comparative Policies and Practices", Georgetown Immigration Law Journal, 13: 617-633.

Yılmaz Eren, E. (2018). Mülteci Hukukunda Geçici Koruma, Ankara: Seçkin.

Zieck, M. (1997). UNHCR and Voluntary Repatriation of Refugees: A Legal Analysis, Martinus Nijhoff Publishers. 